Agnieszka Wandel, Przemiany współczesnej książki popularnonaukowej dla dzieci i młodzieży na przykładzie francuskiej oferty wydawniczej, Towarzystwo Autorów i Wydawców Prac Naukowych „Universitas”, Kraków 2019, 352 ss., ISBN 97883-242-3509-4

https://doi.org/10.19195/0080-3626.63.15

Książki popularnonaukowe stanowią jeden z najważniejszych segmentów produkcji wydawniczej kierowanej do dzieci i młodzieży, pod względem zarówno liczby publikowanych tytułów, jak i drukowanych egzemplarzy. Pomimo takiego statusu często nie znajdują one właściwego miejsca ani w omówieniach badawczych, ani w opracowaniach krytycznych: uwaga naukowców i recenzentów związanych z publikacjami dla niedorosłych jest zdominowana przez książkę literacką. W ostatnich latach w Polsce (ale też na całym świecie) jesteśmy jednak świadkami zmiany tej sytuacji. Wzmożone zainteresowanie książkami edukacyjnymi dla młodych manifestuje się w inicjowaniu nagród dedykowanych temu segmentowi (na przykład „Mądra książka roku”), powstawaniu liczniejszych rekomendacji i omówień w czasopismach literackich (na przykład w czasopiśmie „Książki magazyn do czytania”) czy publikacji o charakterze naukowym. Rozprawa dr Agnieszki Wandel (badaczki z Instytutu Informacji Naukowej i Bibliotekoznawstwa Uniwersytetu Wrocławskiego) Przemiany współczesnej książki popularnonaukowej dla dzieci i młodzieży na przykładzie francuskiej oferty wydawniczej jest bardzo ważnym komponentem takiego trendu.

$\mathrm{Na}$ wstępie warto zwrócić uwagę, że wybór przez autorkę francuskiej oferty wydawniczej jako centralnego tematu rozprawy poświęconej książce popularnonaukowej ma znaczenie podwójnie symboliczne. $Z$ jednej strony kraj ten zawsze będzie się kojarzył z encyklopedystami, pierwszymi popularyzatorami nauki. Z drugiej zaś, bardziej lokalnie, francuska książka popularnonaukowa dla dzieci i młodzieży przez całe ostatnie dekady PRL była przez Polaków oglądana i podziwiana na warszawskich targach książki. W epoce wydawniczej szarzyzny stoiska z publikacjami Larousse'a czy Galimarda olśniewały i wykreowały niedościgły (jak się wówczas wydawało) wzór książki edukacyjnej dla niedorosłych (autorka przywołuje w swojej rozprawie ten kontekst — s. 12-13).

Jednym z pierwszych i całkowicie podstawowych problemów, jakie musiała rozwiązać wrocławska badaczka, była sama nazwa dyskutowanego w książce asortymentu wydawniczego. W polskiej literaturze przedmiotu konkurują z sobą co najmniej trzy pojęcia określające niebeletrystyczną książkę dla dzieci i młodzieży: ,popularnonaukowa”, „edukacyjna”, ,poznawcza” (s. 16). Agnieszka Wandel rozwiązuje ten problem, odwołując się — zgodnie z zakresem rozprawy — do francuskiego pojęcia documentaire, które wedle jej opinii jest najbliższe polskiemu „popularnonaukowy”, które uznaje dalej za obowiązujące (s. 15). W dalszej części tekstu badaczka proponuje interesującą definicję tego rodzaju edycji i deklaruje, że przedmiotem rozprawy będzie

książka, której celem jest upowszechnianie wszelkiego rodzaju faktów i/lub rozmaitych umiejętności w sposób dostosowany do etapu rozwojowego młodego czytelnika i która wyróżnia się ściśle zdeterminowaną funkcją poznawczą (informacyjną) w przeciwieństwie do publikacji o dominującej funkcji estetycznej i/lub rozrywkowej [...]. Książka ta należy do sektora lektur spontanicznych w przeciwieństwie do książki szkolnej. (s. 15-16)

\title{
ROCZNIKI BIBLIOTECZNE
}

ROK LXIII, 2019

(C) for this edition by CNS 
Autorka oparła swoje badania na bardzo zwartej i klarownej metodologii. Przeanalizowała produkcję pięciu wybranych, najbardziej znaczących dla omawianego segmentu francuskich wydawnictw w latach 1982-2012 i na tej podstawie stworzyła bazę danych składającą się z 5382 tytułów wpisujących się w omawianą definicję. Książki te zostały następnie poddane analizie treściowej i formalnej (edytorskiej). Pod uwagę wzięto następujące oficyny wydawnicze: Hachette Jeunese, Galimard Jeunesse, Nathan, Bayard, Larousse. Pierwsze cztery są liderami na francuskim rynku książki dla dzieci i młodzieży. Piąte (Larousse), mimo iż zajmuje miejsce poza pierwszą dziesiątką w takim rankingu, lokuje się bardzo wysoko jako firma specjalizująca się w publikowaniu edycji z omawianego segmentu. Wnioski wysnute z takiej analizy zostały wykorzystane do zidentyfikowania najważniejszych kierunków rozwojowych w edytorstwie książki edukacyjnej dla młodych.

Metoda taka ma bardzo wiele zalet, a jej zastosowanie prowadziło do adekwatnego, szerokiego i wnikliwego zaprezentowania głównej części francuskiej produkcji wydawniczej w omawianym segmencie. Rozpoznając niewątpliwe zalety takiej metody, czytelnikowi może jednak towarzyszyć pewna wątpliwość, odnosząca się do zjawisk natury jakościowej. Czy przy takim wyborze przedmiotów analizy uwadze badaczki nie mogły umknąć z pola widzenia ciekawe zjawiska reprezentowane przez produkty małych, niszowych wydawnictw? Do postawienia takiego pytania skłaniają doświadczenia polskiego rynku książki, gdzie (przynajmniej do niedawna) najciekawsze publikacje przeznaczone dla odbiorcy dziecięcego były oferowane przez „wydawnictwa lilipucie”. Duże koncerny wydawnicze są przecież z reguły raczej konserwatywne w swoich działaniach, ze względu na skostnienie korporacyjnych procedur bardzo rzadko bywają awangardą zmian. Przykładem ilustrującym te wątpliwości może być casus francuskiego tłumaczenia najbardziej znanej polskiej książki edukacyjnej, a jednocześnie światowego bestsellera - Map Aleksandry i Daniela Mizielińskich. Książka została opublikowana we Francji w roku 2012 przez małego wydawcę Rue de Monde. Mapy nie znalazły się więc w zestawie tytułów analizowanych przez A. Wandel — autorka przyznaje, że „[W autorskiej bazie danych] niestety, nie zarejestrowano ani jednej publikacji tłumaczonej na francuski z języka polskiego" (s. 143)1. W dalszej części rozprawy sama autorka przywołuje zresztą wydawnictwo Rue de Monde, przyznając, że takie oficyny wyznaczają „,W tym zakresie [dotyczącym popularnonaukowych książek obrazkowych] najświeższe trendy” (s. 205). Można więc zastanawiać się, czy rozprawy nie wzbogaciłby choć niewielki fragment poświęcony książce niszowej/publikowanej przez niszowe wydawnictwa? Należy jednak podkreślić, że prezentowane uwagi ani nie zmieniają wysokiej oceny metodologii zastosowanej przez autorkę, ani — w ostatecznym rozrachunku — uzyskanego dzięki niej obrazu decydującej części francuskiej produkcji w omawianym segmencie.

Przygotowując książkę, autorka przeprowadziła imponującą kwerendę badawczą: wykorzystała bardzo szeroki zestaw różnego typu źródeł informacji, począwszy od katalogu online Narodowego Centrum Literatury dla Dzieci i Młodzieży (będącego częścią francuskiej Biblioteki Narodowej) przez Centralny Katalog Francuskich Bibliotek Publicznych, globalny Worldcat, bazy danych LivrJeun aż po szwajcarski Ricochet. A. Wan-

1 Trzeba przy tym zaznaczyć, że A. Wandel oczywiście wspomina o publikacji Map we Francji, informuje nawet o przyznaniu książce prestiżowej nagrody Prix Sorcieres (s. 122, przyp. 208).

ROCZNIKI BIBLIOTECZNE

ROK LXIII, 2019

(C) for this edition by CNS 
del zapoznała się także z najważniejszymi i najbardziej aktualnymi omówieniami badawczymi, zarówno francuskimi, jak i polskimi, poświęconymi książce dla dzieci ogólnie oraz publikacjom popularnonaukowym w szczególności. Bardzo cenną część materiału naukowego autorka zdobyła $w$ trakcie trzech pobytów w Paryżu, podczas których mogła dokonać analizy omawianych tytułów z autopsji, brała również udział w największych francuskich targach książki dziecięcej (Salon du Livre et de la presse jeunesse Seine-Saint-Denis).

Przygotowana za pomocą takiej metody i na podstawie opisanej kwerendy książka składa się z dwóch części. Pierwsza z nich, objętościowo mniejsza, zawiera syntetyczny (choć wcale nie pobieżny) rys historyczny, prezentujący drogi rozwojowe książki edukacyjnej dla dzieci i młodzieży we Francji. Autorka dzieli historię francuskiej książki popularnonaukowej na dwa okresy — od początków do końca XIX wieku oraz od początku XX do przełomu XX i XXI wieku. Druga główna część rozprawy A. Wandel oparta jest, jak wspomniano wcześniej, przede wszystkim na analizie książek z przygotowanej przez badaczkę bazy danych. Tę część rozprawy otwiera niezwykle ciekawa prezentacja francuskiego rynku książki dla dzieci: jego segmentów, struktury, danych statystycznych opisujących jego wielkość. Polski odbiorca może z niejaką zazdrością zapoznawać się z kluczowymi danymi liczbowymi, których tak brakuje do rozpoznania rodzimego rynku wydawniczo-księgarskiego. W kolejnym rozdziale autorka dokonuje przeglądu tekstów krytycznych poświęcanych we Francji książce edukacyjnej (wraca tutaj na chwilę także do kwestii terminologicznych) oraz strategiom jej upowszechniania. Kluczowe znaczenia dla rozprawy ma jej piąty rozdział, w którym badaczka stawia swoją podstawową tezę o przełomowym znaczeniu dyskutowanego okresu w historii francuskiej książki edukacyjnej dla niedorosłych. Jednym z głównych zjawisk uzasadniających taką tezę byłoby rozpoczęcie (1983) publikowania innowacyjnych serii wydawniczych, ze szczególnym uwzględnieniem monumentalnej „Découverte Cadet” oferowanej przez Gallimard Jeunesse. W dalszej części rozdziału autorka przeprowadza znakomitą, pogłębioną analizę edytorską kluczowego dla współczesnej książki popularnonaukowej zjawiska serii i kolekcji wydawniczych. Dostrzega najważniejsze zmiany: odejście w edycjach od gutenbergowskiej koncepcji czytania linearnego, od lewej do prawej, od góry do dołu, wprowadzenie skorelowanego z nowym porządkiem czytania układu graficznego - coraz częściej rozkładówki książek popularnonaukowych przypominają strukturą strony internetowe lub witryny internetowych serwisów informacyjnych.

Ważnym, nowatorskim wkładem Agnieszki Wandel do refleksji bibliologicznej nad książką dla niedorosłych jest zaproponowana przez nią w rozdziale szóstym typologia publikacji popularnonaukowych dla dzieci i młodzieży oparta na wyróżniku dominującej formy przekazu. Typologia ta zostaje $\mathrm{w}$ dalszej części rozdziału zastosowana do syntetycznego zaprezentowania tytułów z autorskiej bazy danych. Tematyka utworów (dla starszych odbiorców) z bazy została zaś przez A. Wandel zaprezentowana w porządku odpowiadającym głównym symbolom Uniwersalnej Klasyfikacji Dziesiętnej.

Zrąb główny rozprawy zamyka rozdział siódmy prezentujący trendy rozwojowe w edytorstwie francuskiej książki edukacyjnej dla młodych. W tej części rozprawy uwagę zwracają choćby rozważania dotyczące zastosowania poczucia humoru, komizmu w publikowaniu tego - wydawałoby się — najpoważniejszego segmentu „dziecięcego”. 
Jednak kluczowym komponentem tej części książki jest dyskusja nad relacjami między „klasyczną" papierową książką edukacyjną a mediami elektronicznymi. Autorka przywołuje tutaj przykłady różnych rozwiązań stosowanych przez francuskich wydawców, łączących wynalazek Gutenberga z elektronicznymi technologiami: strony WWW związane z poszczególnymi tradycyjnie opublikowanymi tytułami, płyty CD czy DVD załączane do papierowych kodeksów lub próby wykorzystania technologii AR (augmented reality) do wizualizowania ilustracji książkowych.

Ważną i godną dostrzeżenia częścią rozprawy są materiały uzupełniające, swego rodzaju aneksy. W szczególności warto zwrócić uwagę na Tablicę chronologiczna. Historia francuskiej książi popularnonaukowej dla dzieci i młodzieży w skrócie (s. 294-296). Autorka zamieściła tutaj w porządku chronologicznym, z adnotacjami, tytuły książek i serii, które wniosły znaczące - często rewolucyjne — zmiany do koncepcji publikacji edukacyjnych. Już samo zapoznanie się z tym dodatkiem pozwala czytelnikowi wyodrębnić najważniejsze etapy ewolucji, jakiej podległa ta część piśmiennictwa.

Docenienia wymaga również strona formalna recenzowanej publikacji: charakteryzuje się ona bardzo staranną edycją, ma przyciągającą wzrok okładkę o wysokich walorach artystycznych. Tekstowi towarzyszą właściwie dobrane ilustracje, dobrze przygotowane i wydrukowane na kredowym papierze świetnej jakości. Obcowanie z książką wrocławskiej badaczki dostarcza czytelnikowi prawdziwej satysfakcji estetycznej!

Ze względu na wszystkie wspomniane zalety książka dr Agnieszki Wandel będzie stanowić przez długi czas obowiązkowe i niezastąpione źródło informacji (ale także inspiracji) dla każdego bibliologa zajmującego się książką popularnonaukową w ogóle, a publikacjami dla dzieci i młodzieży w szczególności. Tytuł ten będzie również ważną lekturą dla badaczy współczesnej książki francuskiej. Przemiany wspótczesnej ksią̇ki... znajdą na pewno także wdzięcznych czytelników w innych kręgach profesjonalistów związanych z książką: bibliotekarzy, wydawców (zwłaszcza tych, którzy myślą o współpracy z oficynami we Francji lub planują inwestycje w segmencie publikacji edukacyjnych) czy nawet ambitniejszych księgarzy.

Michat Zając 